\title{
EFFECT OF PHSICO-HYDRAULIC PROPERTIES ON TOMATO NURSERY
}

\author{
F. I. Zabady ${ }^{*}$
}

\section{ABSTRAT}

The main objective of this study was to find the best mixture (growth media) for planting tomato nursery by mixing sand, peatmoss, and vermiculite. The mixtures were devided to three groups (sand + peatmoss), (sand + vermiculite), and (sand + peatmoss + vermiculite). Each group contains different ratio of sand and other component. Also, one sample was $(40 \%$ petmoss $+60 \%$ vermiculite) as a control. Laboratory experiments were conducted to quantify real density ( $\mathrm{g} / \mathrm{cm} 3)$, bulck density (g/cm3), hydraulic conductivity $(\mathrm{cm} / \mathrm{min})$, total porosity (\%), and water holding capacity $(\mathrm{g} / \mathrm{g})$ as affected by different mixtures. The tomato nursery was planted into trays in greenhouse. The results show that in the media of "sand + peatmoss" increased sand ratio gave an increase in total porosity and a decrease in water holding capacity. At mixtures of "sand + vermiculite", the total porosity decreased with increase in sand ratio and water holding capacity decreased with an increase in sand ratio. The highest values of total porosity and water holding capacity were at mixture of $(70 \%$ peatmoss $+30 \%$ sand). Also, the highest growth parameter of nursery as seedling weight and length was obtained with the same mixture.

\section{INTRODUCTION}

$\mathrm{F}$ avorable media (good drainage, absence of toxicity, fertility, etc.) are indispensable for the success of a nursery. When nursery plants are raised in pots, polybags, seed boxes or trays, it may not be necessary for soils on the nursery site to be fertile. Media must perform 4 functions (1) provide a stable substrate for root anchorage, (2) provide a reservoir of nutrients, (3) provide oxygen (gas exchange) for roots and provide water for roots.

Therefore, best media should contain 50 to $85 \%$ pore space. Total porosity of media is important, but probably more crucial is the portion

\section{${ }^{*}$ Asst. Prof. Agric. Eng. Dept., Fac. of Agric., Cairo, Al-Azhar Uni.}


of air space versus water holding capacity "WHC.". Some plants prefer wet soil while others prefer dry soils. An average of 10 to $30 \%$ of the media volume should be composed of air space while 45 to $65 \%$ should be water. In some ways, vermiculite is similar to perlite in that they both originate as mined minerals that are then heated to produce a finished product. Perlite and vermiculite differ, however, in the rationale for including them in a mix. Perlite is usually included in a mix to increase drainage, but does not increase the retention of nutrients. In contrast, vermiculite with its plate-like structure holds large quantities of water and positive charged nutrients like potassium, magnesium and calcium. The $\mathrm{pH}$ of vermiculite will vary depending on where it is mined. Most US sources are neutral to slightly alkaline, whereas vermiculite from Africa can be quite alkaline $(\mathrm{pH}=9)$. Vermiculite is used extensively in the greenhouse industry as a component of mixes. Sand is a common amendment used in propagation applications and is occasionally used in a greenhouse or nursery mix. Sand is typically selected as a media component to improve the drainage. While sand represents a wide range in particle sizes, growers generally use medium to coarse sands $(0.25$ to 2 $\mathrm{mm})$. Peat is a very common component in mixes. Peat is usually included in a mix to increase the water-holding capacity or to decrease the weight. Peatmoss is the least decomposed form of the peat types, is typically light tan to brown in color, lightweight, high in moistureholding capacity and very acidIC (pH 3.8 to 4.3 ). A significant problem with peatmoss derived from reed-sedge or hypnum peatmoss represents an advanced stage of decomposition. This type of peat is usually dark brown to black and has a low moisture-retention capacity James (2011).

Yusef (2011) stated that the best mixture (growth medium) for planting Dahli, Marigold, Zinnia and Cosmos is by mixing date palm leaves compost with vermiculite, perlite, sand and clay. He reported that generally, date palm leaves compost + vermiculite mixture improved the vegetables growth of plants better than other mixtures. On relative basis, the mean biomass of all the plant grown in date palm leaves compost was $80 \%$ and $71 \%$ of those plants grown in date palm leaves compost + vermiculite $(2: 1)$ respectively. Mean plants height of marigold was 
about $29.6 \%$ higher in date palm leaves compost + vermiculite (1:2) as compared to pure date palm leaves compost.

Prasad (1978) stated the effect of addition of sand, perlite, polystyrene and pumice in helf and proportions and in various particle sizes, on physical properties of peat mixes. He found that coarse sand had no effect on air space, while fine sand reduced air space and at higher rate, the value fell to unsatisfactory level. At the higher rate of coarse sand additions, easily available water fell to unsatisfactory level. Fine sand increased easily available water, total porosity reduced as a result of sand addition. The addition of coarse perlite at the higher rate increased the air space, while fine perlite at both rates and medium perlite rate reduced air space. The effect of addition of coarse and fine perlite on easily available water was similar to sand addition. Total porosity was reduced by coarse perlite and by medium perlite addition at the higher rate. The addition of polystyrene increased air space, but decreased easily available water and the value fell to unacceptable level at the high rate of application.

In this study some growth parameters were measured as nursery seedling height, leaves number, nursery weight, and germination ratio, by using different media which had different ratios of sand, peatmoss, and vermiculite, to produce tomato nursery production.

\section{MATERIALS AND METHODS}

\section{MATERIALS}

Laboratory experiments were carried out in the Irrigation Laboratory, Agriculture Engineering Department, Al-Azhar University, Nasr City, Cairo. The main objective of the laboratory experiments were to determine the characteristics of different mixture media samples such as: real density, bulck density, hydraulic conductivity, total porosity, and water holding capacity for cultivating the tomato nursery.

Eleven samples were made for mixtures which varied in volumetric proportions of sand, peatmoss, and vermiculite. The coarse sand ratio varied from $30 \%$ to $50 \%$; peatmoss from $35 \%$ to $80 \%$ and vermiculite from $20 \%$ to $80 \%$ (Table: (1)). 


\section{Tomato:}

Tomato (Lycopersicon esculentum Mill), which is cultivated in trays for home consumption and commercial domestic market, processing plants and exporting, is one of the world's most popular vegetables (FAO, 1989). It also possesses valuable medical properties, an excellent purifier of blood and a rich source of vitamins like vitamin $\mathrm{A}$ and $\mathrm{C}$ than any other vegetables (Villareal, 1978). Good quality of seedling usually leads to higher yield and earlier maturity. Tomato that mature early not only could receive higher price on fresh market, but also could reduce the risk involved in growing tomatoes in the tropics. The growth parameters were measured as: seedling length, leaves number, weight, and germination ratio.

Table (1): Ratios of sand (\%), peatmoss (\%), and vermiculite (\%) for each treatment in the present study.

\begin{tabular}{|c|c|c|c|}
\hline \multirow{2}{*}{ Treatment } & \multicolumn{3}{|c|}{ Mixture ratios } \\
\cline { 2 - 4 } & Peat. \% & Vermi. \% & Sand \% \\
\hline A & 50 & -- & 50 \\
\hline B & 60 & -- & 40 \\
\hline C & 70 & -- & 30 \\
\hline D & 80 & -- & 20 \\
\hline E & -- & 60 & 40 \\
\hline F & -- & 70 & 30 \\
\hline G & -- & 80 & 20 \\
\hline H & 60 & 40 & -- \\
\hline I & 35 & 35 & 30 \\
\hline J & 40 & 30 & 30 \\
\hline K & 60 & 20 & 20 \\
\hline
\end{tabular}




\section{Cell trays:}

Cell trays are used by commercial growers to produce seedlings for planting out. The seedlings are easily removed from the tray for transplanting, and the growth check to transplants from cell trays is minimal when planted in the field, compared to the use of other types of transplants. The dimension of trays was $(40 \times 80 \mathrm{~cm})$ and $(11 \times 19)$ csells. The trays were made from foam.

\section{METHODS}

Saturated hydraulic conductivity " $K_{\mathrm{s}}$ ":

Saturated hydraulic conductivity " $\mathrm{K}_{\mathrm{s}}$ " $(\mathrm{cm} / \mathrm{h})$ of the media samples were measured (three replicates per treatment) using the constant head method as described by Stolte (1997).

\section{Real density, bulck density, and total porosity:}

Dry bulck density $\left(\mathrm{g} / \mathrm{cm}^{3}\right)$ was calculated (dry weight basis) for each sample by weighting $400 \mathrm{ml}$ of beakers filled with the soil mixture. Samples were oven dried at $105^{\circ}$ for 24 hour, and weighted again. The bulck density was determined as dry soil mass per media volume. Real density $(\mathrm{g} / \mathrm{cm} 3)$, bulck density $(\mathrm{g} / \mathrm{cm} 3)$, and total porosity $(\%)$ were determined according to Klute (1988).

\section{Moisture holding capacity:}

Moisture holding capacity was measured on a dry weight basis according to the following equation (Thompson et al. 2008):

$$
\text { M.H.C }=\frac{M_{f}-M_{d}}{M_{d}}
$$

\section{Where:}

$\mathbf{M}_{\mathbf{f}}$ : is the mass ( $\mathrm{g}$ ) of the sample at field capacity, $\mathbf{M}_{\mathbf{d}}$ : is the mass (g) of the dry sample. 


\section{RESULTS AND DISCUSSION}

The main objective of this study was to determine some physical properties and watering characteristics of different media samples and their effects on growth parameters of tomato nursery.

\section{Sand peatmoss mixture:}

Fig. (1) illustrate the relation between real density $\left(\mathrm{g} / \mathrm{cm}^{3}\right)$, bulck density $\left(\mathrm{g} / \mathrm{cm}^{3}\right)$, and hydraulic conductivity $(\mathrm{cm} / \mathrm{min})$ at different ratios of sand with peatmoss.

It will be noticed that at increasing sand ratio from $20 \%$ to $50 \%$ leads to decrease the hydraulic conductivity from 4.5 to $2.1 \mathrm{~cm} / \mathrm{min}$ respectively, while the bulck density increased from 0.45 to $0.86 \mathrm{~g} / \mathrm{cm}^{3}$ and real density increased from 1.5 to $2 \mathrm{~g} / \mathrm{cm}^{3}$.

Fig. (2) revealed that represent total porosity (\%) at different sand ratios which increased from $20 \%$ to $50 \%$. The figure shows an increase of total porosity from 59.6 to $65.1 \%$ with the increase sand ratio.

\section{Sand vermiculite mixture:}

Fig. (3) shows the relations between real density $\left(\mathrm{g} / \mathrm{cm}^{3}\right)$, bulck density $\left(\mathrm{g} / \mathrm{cm}^{3}\right)$, and hydraulic conductivity $(\mathrm{cm} / \mathrm{min})$ at different ratios of sand with vermiculite. It is indicated that the real density, bulck density, and hydraulic conductivity were increased with the increased of sand ratio. However, Fig. (4) illustrates that the total porosity decreased with sand + vermiculite ratio.

\section{Treatments of $\mathrm{H}, \mathrm{I}, \mathrm{J}$ and $\mathrm{K}$ :}

Figs. (5) and (6) show the effect of different mixture ratios from (sand + peatmoss + vermiculite) on the real density, bulck density, total porosity, and hydraulic conductivity. From these figures, the highest total porosity was $72.9 \%$ at " $\mathrm{H}$ " treatment ( $60 \%$ peatmoss $+40 \%$ vermiculite). Also, the highest hydraulic conductivity was $2.6 \mathrm{~cm} / \mathrm{min}$ at "H" treatment $(60 \%$ peatmoss $+40 \%$ vermiculite) . 


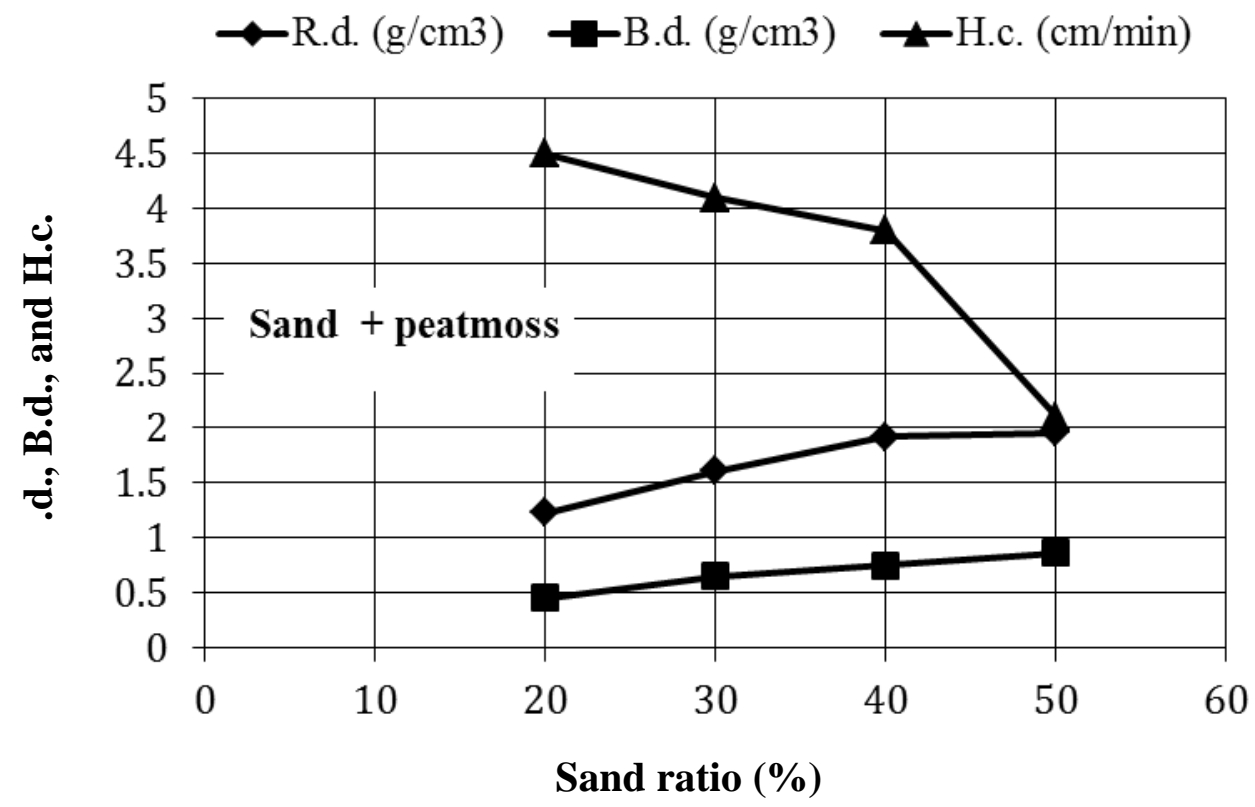

Fig. (1): Relation between real density "R.d" (g/cm3), bulk density "B.d" (g/cm3), and hydrualic conductivity "H.c" (cm/min) and sand ratio for sand peatmoss mixture.

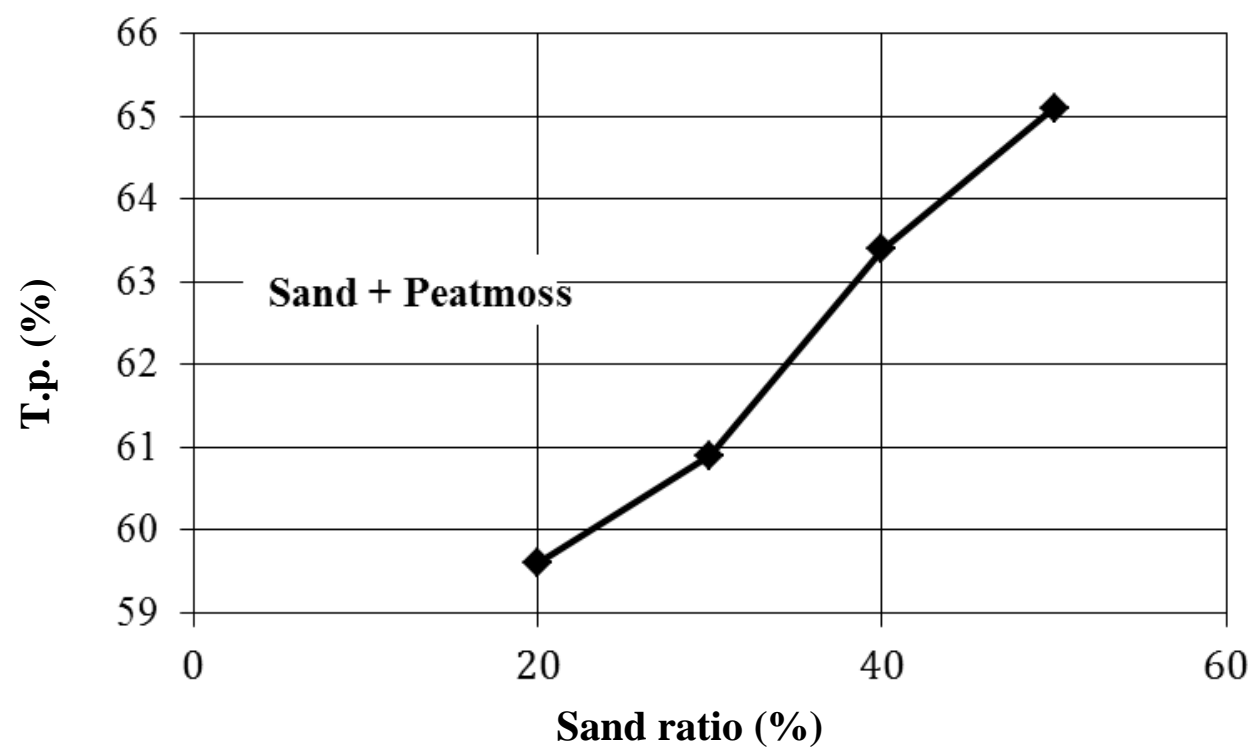

Fig. (2): Relation between total porosity "T.p." (\%) and sand ratio for sand peatmoss mixture. 
$\neg-$ R.d. $(\mathrm{g} / \mathrm{cm} 3) \rightarrow$-B.d. $(\mathrm{g} / \mathrm{cm} 3) \rightarrow$ H.c. $(\mathrm{cm} / \mathrm{min})$

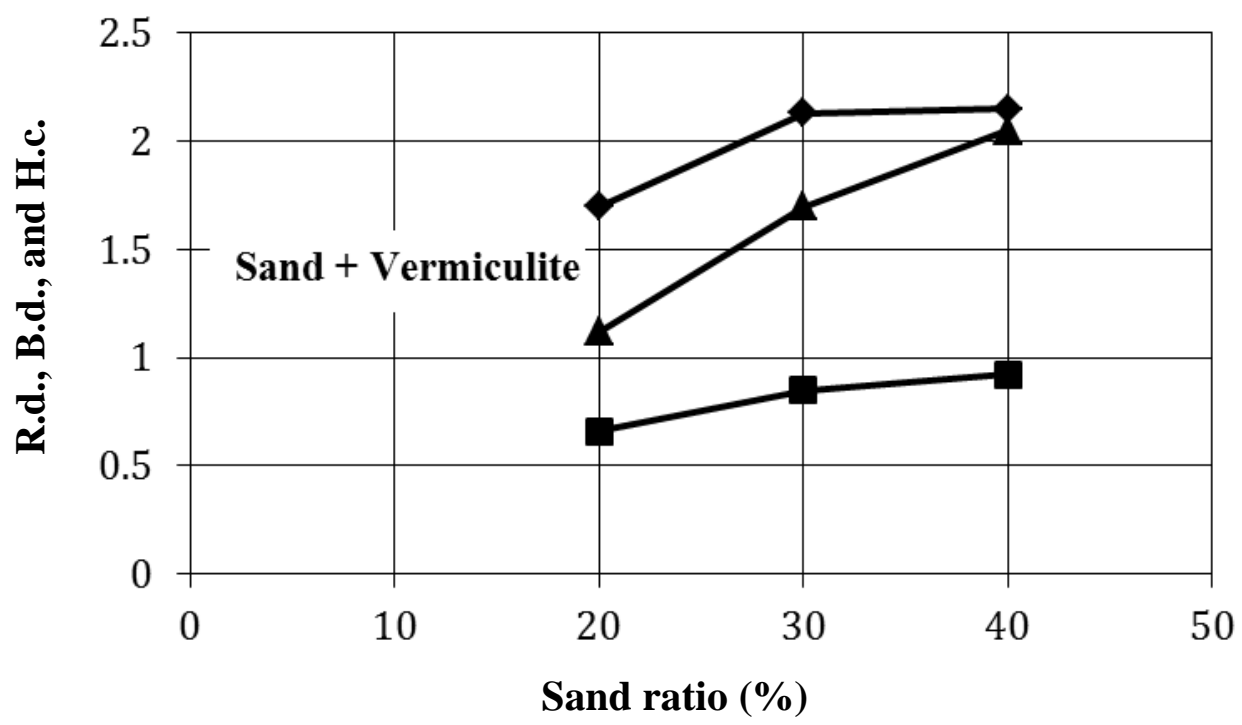

Fig. (3): Relation between real density "R.d" (g/cm3), bulk density "B.d" (g/cm3), and hydraulic conductivity "H.c" (cm/min) and sand ratio for sand vermiculite mixture.

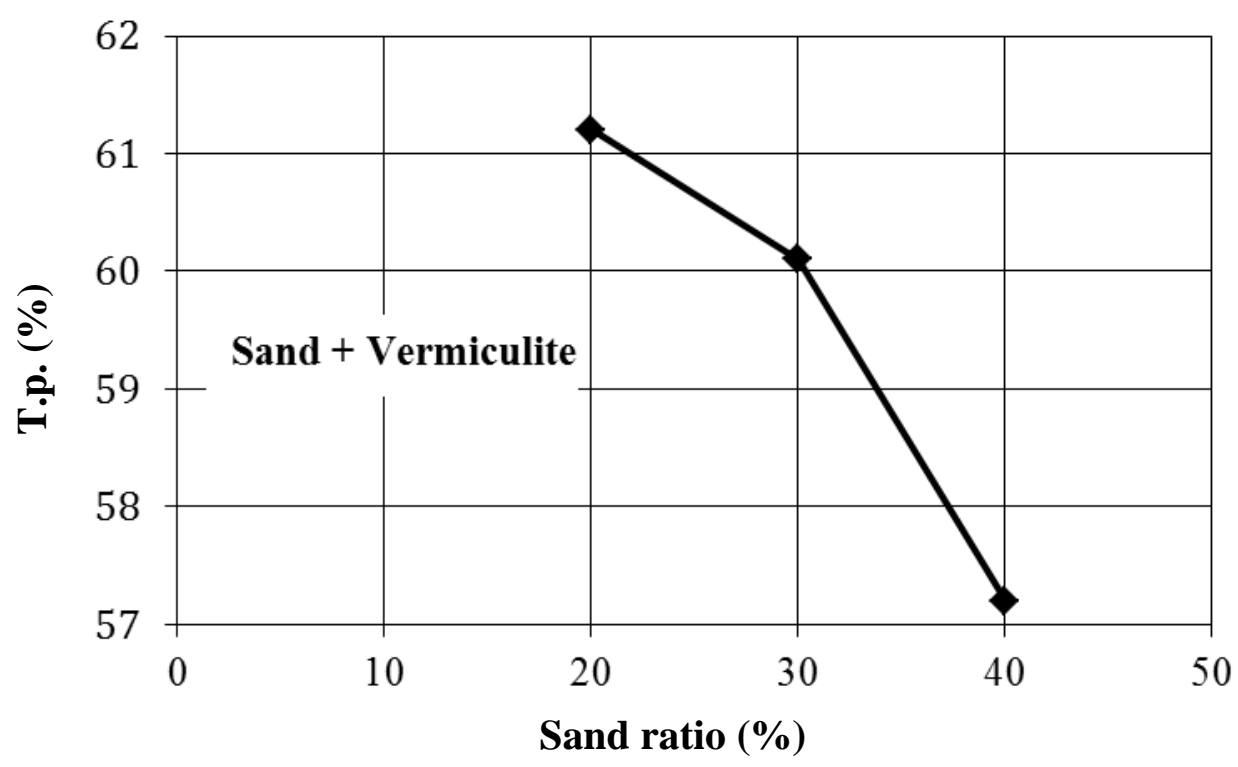

Fig. (4): Relation between total porosity "T.p." (\%) and sand ratio for sand vermiculite mixture. 
a.d. $(\mathrm{g} / \mathrm{cm} 3) \quad=$ B.d. $(\mathrm{g} / \mathrm{cm} 3) \quad \approx$ H.c. $(\mathrm{cm} / \mathrm{min})$

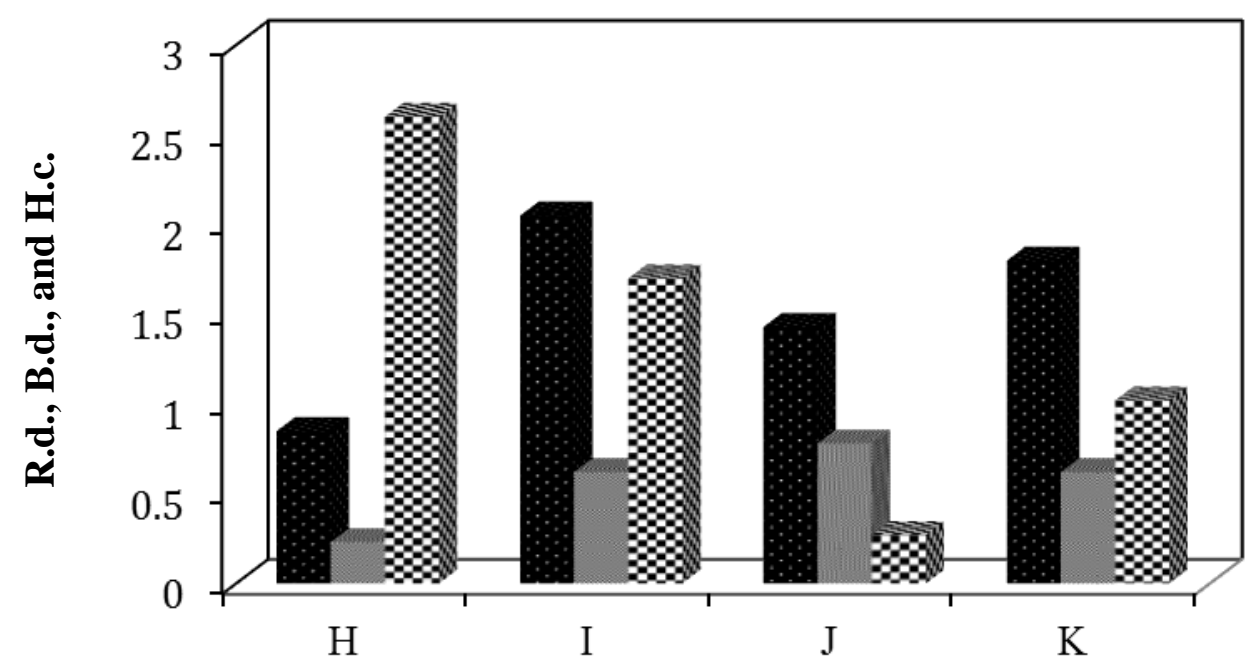

Treatments

Fig. (5): Relation between real density "R.d" (g/cm3), bulk density "B.d" (g/cm3), and hydraulic conductivity "H.c" (cm/min) and treatments of $I, J$, and $K$.

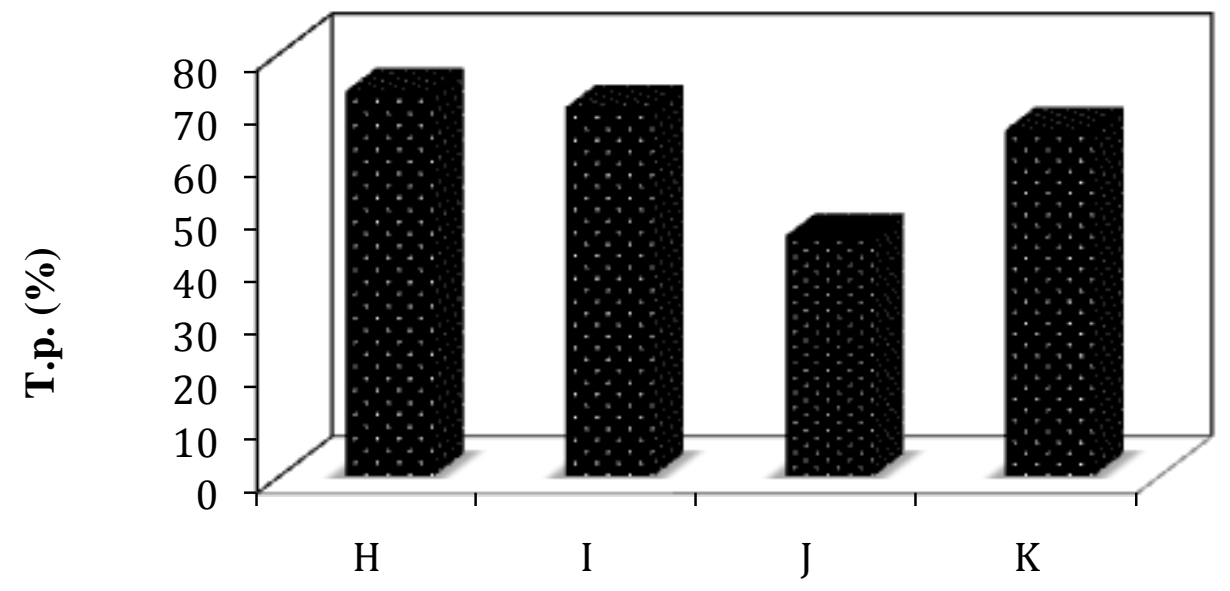

Treatments

Fig. (6): Relation between total porosity "T.p." (\%) and treatments of $\mathbf{I}, \mathbf{J}$, and $\mathrm{K}$. 
Fig. (7) shows water holding capacity $(\mathrm{g} / \mathrm{g})$ for different treatments. Its clear that the highest value of water holding capacity was $3.82 \mathrm{~g} / \mathrm{g}$ for "H" treatment $(60 \%$ peatmoss $+40 \%$ vermiculite) and the lowest value was $0.52 \mathrm{~g} / \mathrm{g}$ for "I" treatment ( $35 \%$ peatmos $+35 \%$ vermiculite $+30 \%$ sand).

\section{Growth parameter:}

Growth parameter as: nursery length, nursery weight, nursery leaves number, and germination ratio which influenced by media components are shown in Figs. (8), (9), and (10). The results showed that the highest values of growth parameters were obtained at media "C" (30\% sand + $70 \%$ peatmoss). These results may be at reputed to balance of air and water in media. Also, the best germination ratio was at the same media.

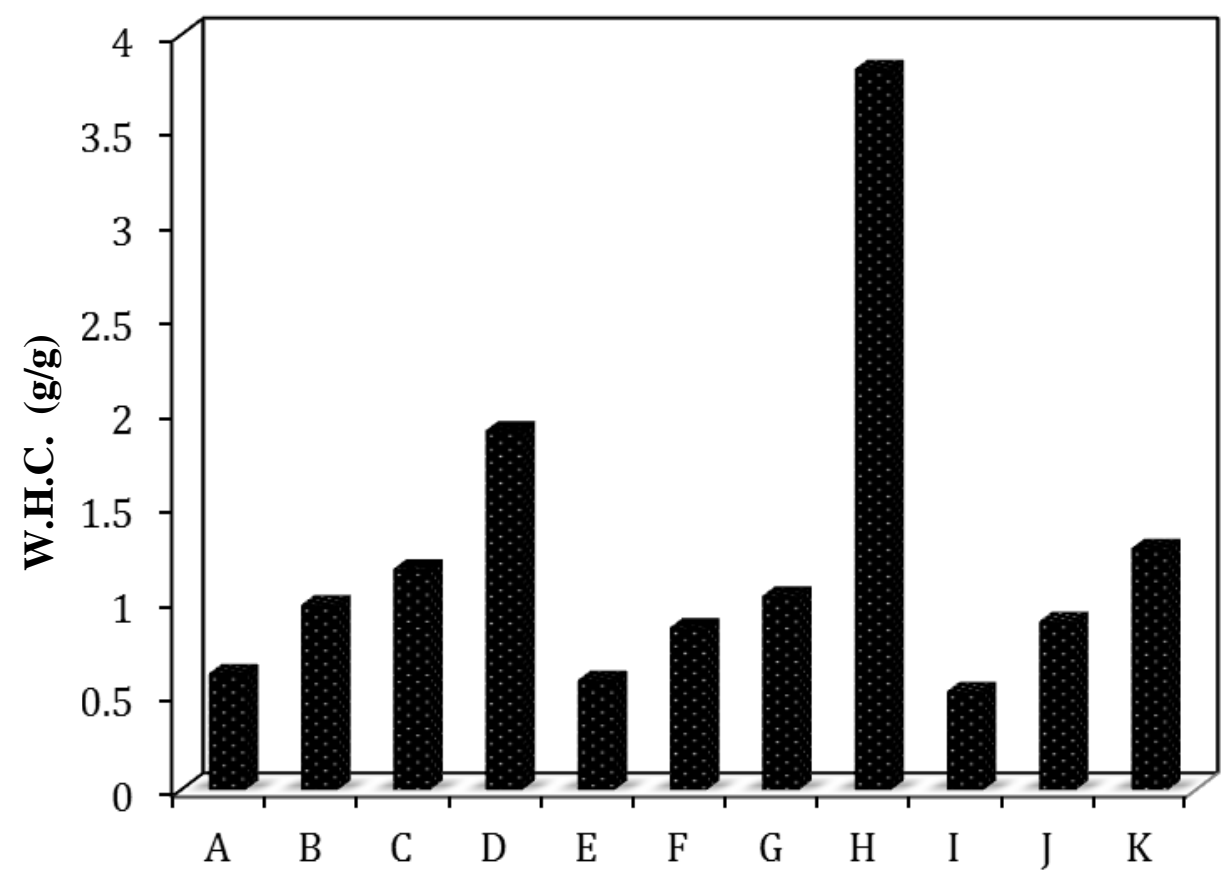

Treatments

Fig. (7): Relation between water holding capacity "W.H.C" (g/g) and different treatments. 


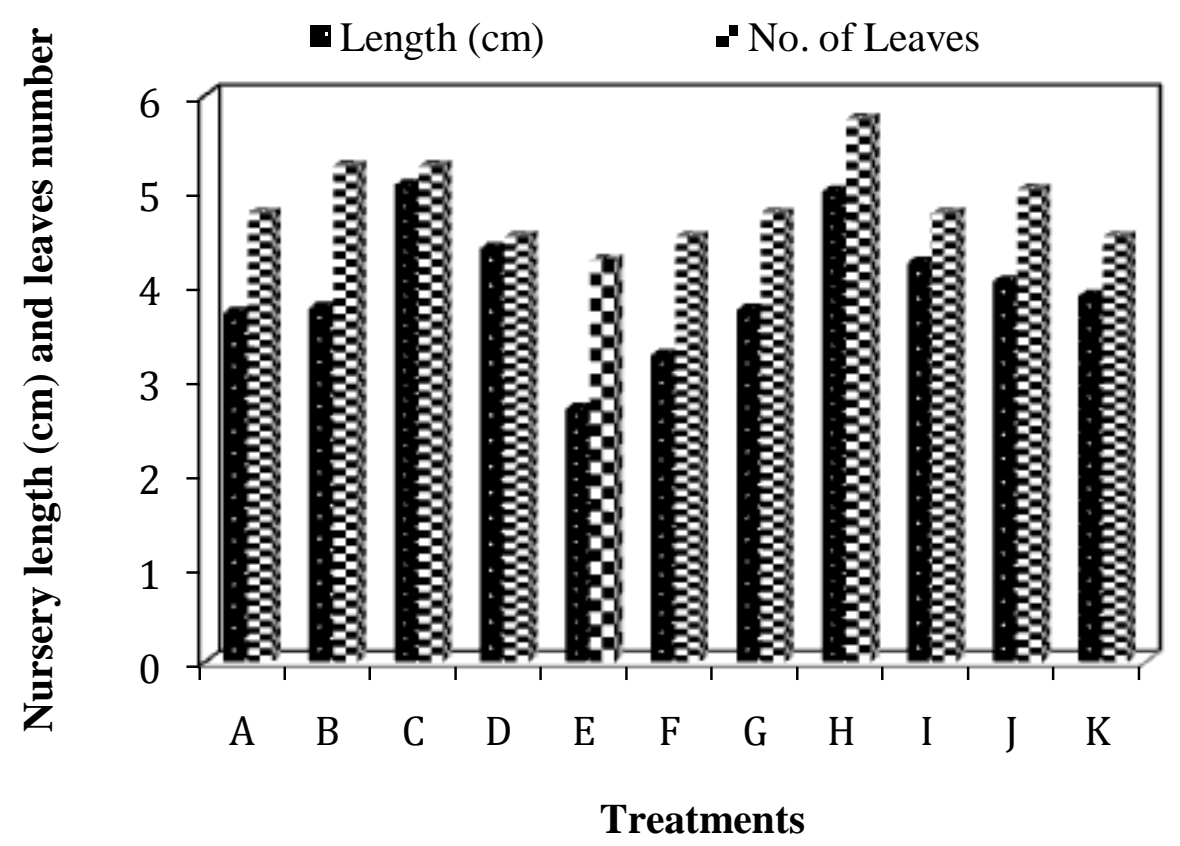

Fig. (8): Relation between growth parameters of nursery length $(\mathrm{cm})$ and leaves number for different treatments.

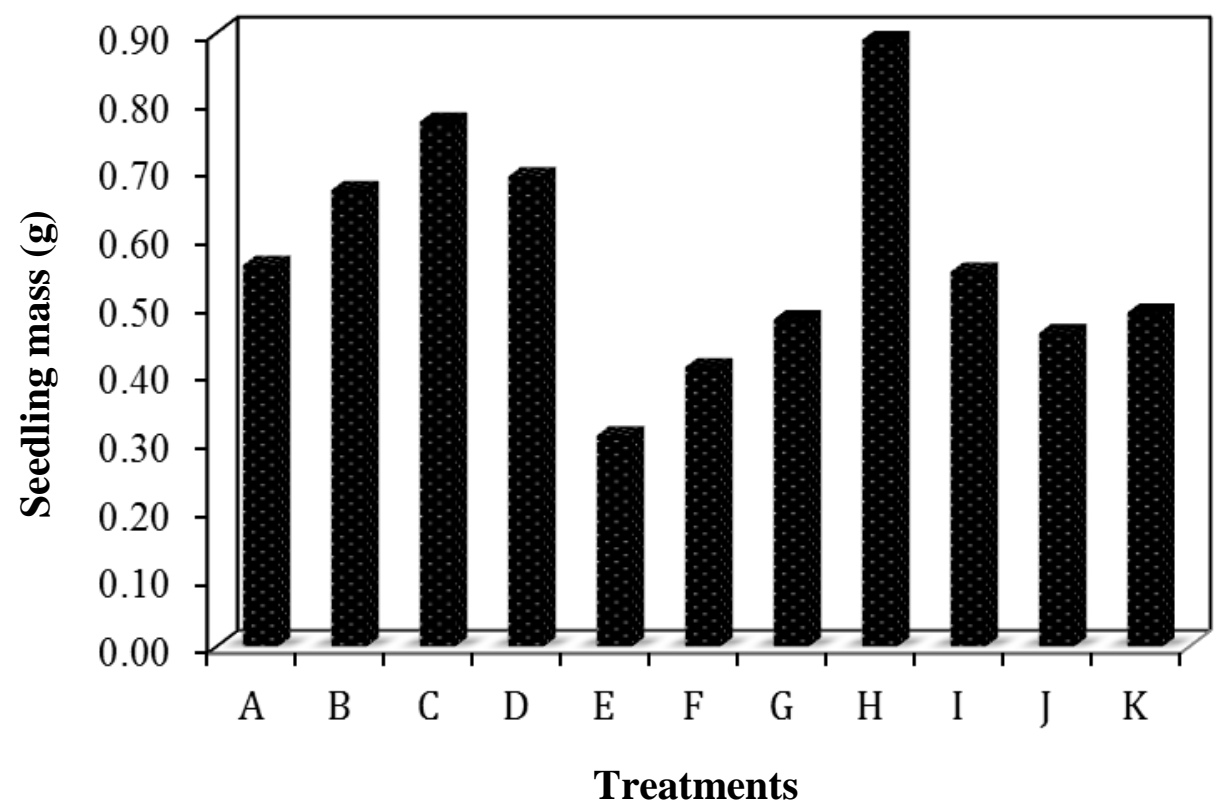

Fig. (9): Relation between seedling mass (g) and different treatments. 


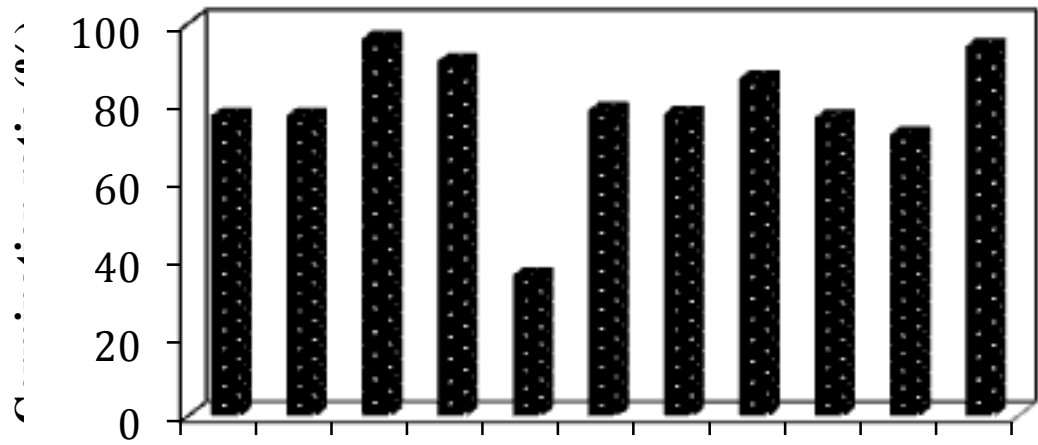

$\begin{array}{llllllllllll}\text { A } & \text { B } & \text { C } & \text { D } & \text { E } & \text { F } & \text { G } & \text { H } & \text { I } & \text { J } & \text { K }\end{array}$

\section{Treatments}

Fig. (10): Germination ratios for different treatments. CONCLUSIONS

For the first four mixture samples "A, B, C, and D", by increase of peatmoss $(50 \%-80 \%)$ and decrease of coarse sand $(50 \%-20 \%)$ in media, the hydraulic conductivity and water holding capacity increased. Meanwhile, the bulck density and total porosity decreased. With the next three treatments "E, F, and G", increase of vermiculite $(60 \%-80 \%)$ and decrease of coarse sand $(40 \%-20 \%)$ of media, increased the water holding capacity and total porosity. Meanwhile the bulck density and hydraulic conductivity decreased.

For the last four mixture samples "H, I, J, and K", which have different ratio (sand + peatmoss + vermiculite), the highest values of hydraulic conductivity, total porosity, and water holding capacity were obtained with treatment "H" ( $0 \%$ sand $+60 \%$ peatmoss $+40 \%$ vermiculite $)$. The highest value of growth parameters as nursery weight and length were obtained at treatment of ( $30 \%$ sand $+70 \%$ peatmos).

Plant media influenced the growth of tomato nursery, in which media of treatment " $\mathrm{H}$ " (60\% peatmoss $+40 \%$ vermiculite) was the best, since seedling height and weight were morer than those with the other media.

\section{REFERENCES}

FAO, (1989). Production year. Vol: 43 . FAO.Rome.

James, A., (2011). Physical properties of container media. Ph.D. North Willamette Res and Ext Center, Oregon State U. http://oregonstate.edu/dept/nursery- weeds/feature 
Klute, A., (1988). Methods of soil analysis part 1 "physical mineralogical methods" $2^{\text {rd }}$ Ad., Am Society Agrony monograph N9 Madison, Wisconsin, USA.

Prasad, M., (1978). Physical properties of media for container-grown crops. II. Peat mixes. Hort Res Center, Res. Div. Mini Ag. and fisheries, Levin New Zealand.

Stolte, J., (1997). Determination of the saturated hydraulic conductivity using the constant head method. Manual for soil physical measurments. Version:3,pp77. DLO, winand staring center. Wageningen. The Nether Lands.

Thompson A. M., A. C. Paul, and N. J. Balster, (2008). Physical and hydraulic properties of engineered soil media for Bioretention Basins. Trans. of th ASABE. Vol: 51 (2): 499-514.

Villareal, R.L., (1978). First international Symposium on Tomato AVRDC,shahua, Tainan, Taiwan, China.

Yusef, S., (2011). Effect of mixing date palm leaves compost (DPLC) with vermiculite, perlite, sand and clay on vegetative growth of dahlia (Dahlia pinnata), Marigold (Tagetes erecta), Zinnia (Zinnia elegans) and Cosmos (Cosmos bipinnatus) Plants. J. of Env Sc 5(7): 655-665.

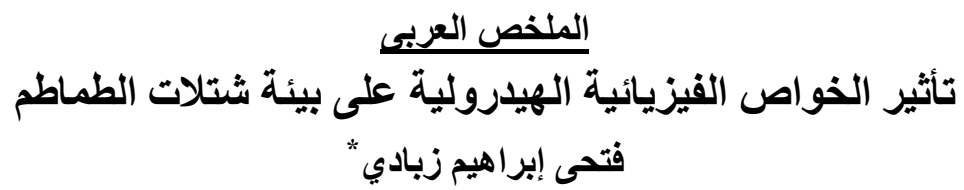

تعتبر الثتلة هى اللبنة الأولى فى حياة النبات. وفى الآونة الأخيرة زاد الطلب على شتلات الخضر خاصةً شتلات الطماطم، وذللك لارتفاع ثمن البذور الهجين و التى تعطى إنتاجية عالية من

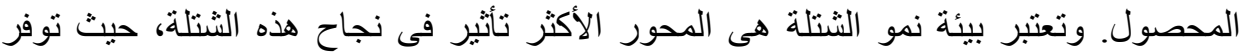

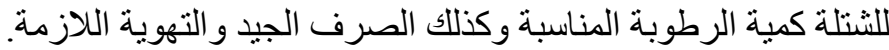

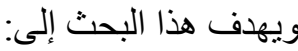

دراسة بعض الخواص الهيدرولية والطبيعية مثل الكثافة الحقيقية والظاهرية و المسامية الكلية

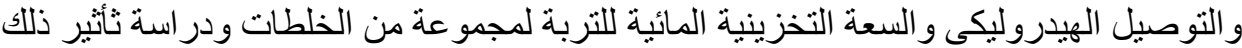

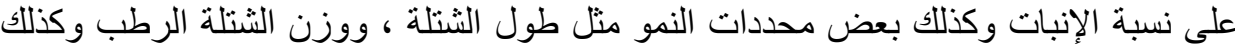

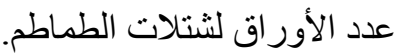

" مدرس الهنسة الزراعية ـ قسم الهنسة الزراعية ـ كلية الزراعة بالقاهرة - جامعة الأزهر. 
وكاتت الخلطات كما يليى:

\begin{tabular}{|c|c|c|c|}
\hline \multicolumn{3}{|c|}{ نسب الخلط } & \multirow{2}{*}{ المعاملة } \\
\hline الرمل (\%) & فيرموكليت (\%) & بيتموس (\%) & \\
\hline$\% 0$. & -- & $\% 0$. & $\mathbf{A}$ \\
\hline$\% \varepsilon$. & -- & $\% 7$. & $\mathbf{B}$ \\
\hline$\%$ \%. & -- & $\% \vee$. & $\mathbf{C}$ \\
\hline$\%$ r. & -- & $\% \wedge$. & D \\
\hline$\% \varepsilon$. & $\% 7$. & -- & $\mathbf{E}$ \\
\hline$\%$ \%. & $\% \vee$. & -- & $\mathbf{F}$ \\
\hline$\%$ r. & $\% \wedge$. & -- & $\mathbf{G}$ \\
\hline- & $\% \varepsilon$. & $\% 7$. & $\mathbf{H}$ \\
\hline$\%$ \%. & $\%$ ro & $\%$ एo & $\mathbf{I}$ \\
\hline$\%$ \%. & $\%$ \%o & $\% \varepsilon$. & $\mathbf{J}$ \\
\hline$\%$ r. & $\%$ r. & $\% 7$. & $\mathbf{K}$ \\
\hline
\end{tabular}

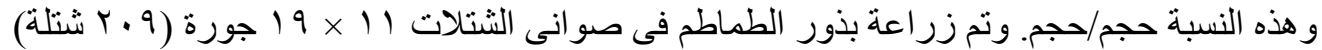

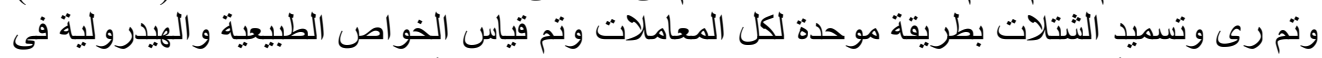

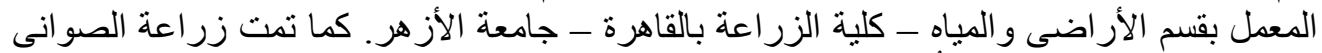

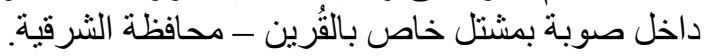
وكاتت النتائج كما يلهي: داهن

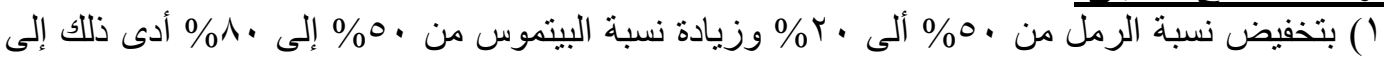

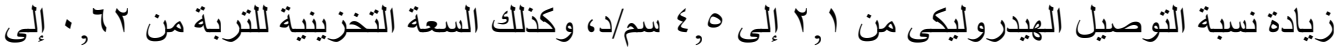

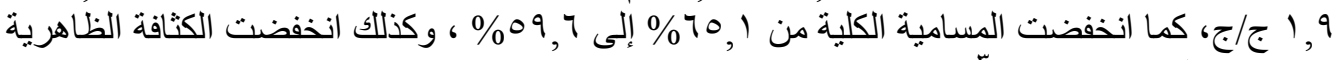

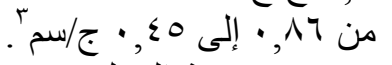

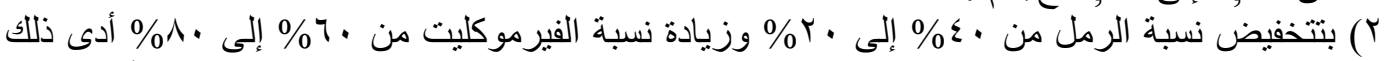

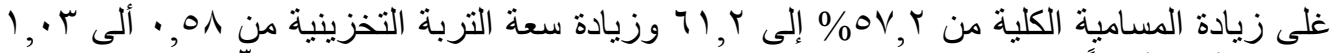

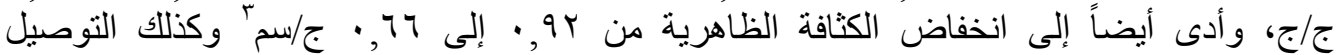

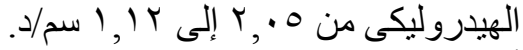

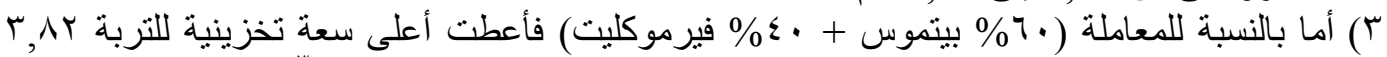

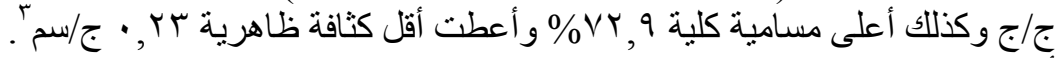
ع) أما بالنسبة للمعاملات I, J, K ثلاثية الخلط (رمل + بيتموس + فيرميكليت) فدلت النية النتائج بزيادة نسبة

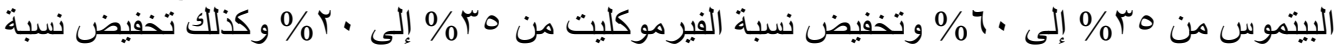

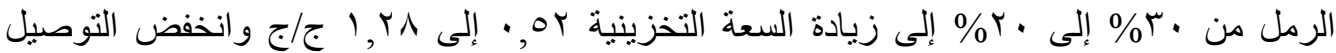

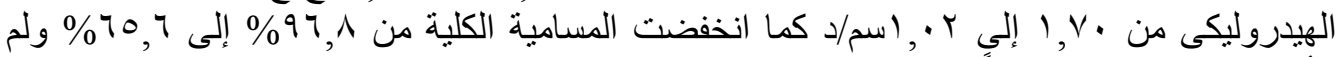
تتأثز الكثافة الظاهرية كثير آ.

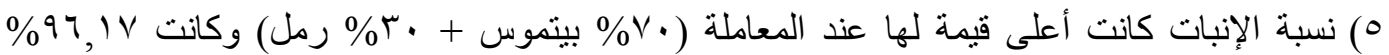

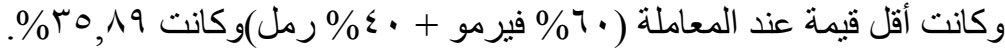

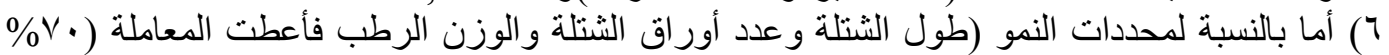

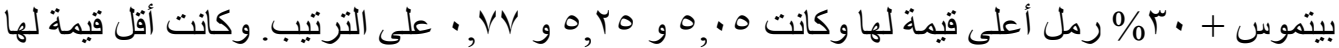

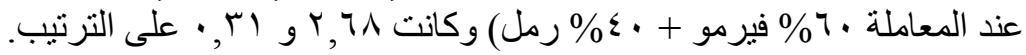

